\title{
EMPLOYEES' KNOWLEDGE DETERMINANTS IN SMEs: THE CASE OF SLOVENIA
}

\author{
Doris Omerzel GOMEZELJ ${ }^{1}$, Boštjan ANTONČIČ² \\ ${ }^{1}$ Department of Entrepreneurship, Faculty of Management, University of Primorska, \\ Cankarjeva 5, Koper, Slovenia \\ ${ }^{2}$ Department of Entrepreneurship Faculty of Economics, University of Ljubljana, \\ Kardeljeva ploščad 17, Ljubljana, Slovenia \\ E-mails: 1doris.gomezelj@fm-kp.si (correspondingauthor); ${ }^{2}$ b.antoncic@gmail.com
}

Received 29 June 2012; accepted 24 September 2012

\begin{abstract}
This paper presents various definitions of knowledge as human capital, and analyses some fundamental challenges regarding the measurement of employees' knowledge of a firm, especially in small and medium enterprises (SMEs). The paper reviews the literature pertaining to the assessment of knowledge assets, proceeds to develop a model of SME employees' knowledge, and presents the results of an empirical test conducted among 173 Slovenian SMEs. Scales were tested for reliability and validity. A structural equation modelling technique was used to verify the theoretically proposed model of the employees' knowledge. The multidimensionality of the developed SME knowledge construct was confirmed. The proposed model of the employees' knowledge consists of five main dimensions: innovation capabilities and willingness to learn, attitude, job qualification, formal education, and work experience. To verify and confirm the proposed model, an exploratory and confirmatory factor analysis was performed. The new construct and concept developed in this study offers a near complete picture that can be used as a research framework in future examinations of the importance of knowledge for SME performance.
\end{abstract}

Keywords: SME, human capital, knowledge, skills, competencies, structural equation modelling.

Jel Classification: L26, D83.

\section{Introduction}

The aim of this paper is to present some fundamental definitions of knowledge as human capital, and to analyse some fundamental challenges regarding the measurement of employees' knowledge of their firm, especially small and medium enterprises (SMEs). It reviews the literature pertaining to the assessment of knowledge assets. Knowledge assets are becoming significantly important for a firm's performance and competitiveness. However, the measurement of such assets is very difficult. This paper includes an approach to determine the measures of employees' knowledge. It is not merely a theo- 
retical reflection, but also outlines the development of an empirical model of employees' knowledge for the firms.

Traditionally, the physical assets of a firm were considered the key success factor, but contemporary views consider human capital to be the most important factor. The production of ideas and the competences of the employees have become tools. The critical source of capital of a firm has changed from a physical to an intellectual form (Belasco, Stayer 1994). This means that firms are presently faced with the fact that they should focus their asset management on human capital. Traditionally, physical capital was the subject of strategic company management. The review of the literature shows that there is no unique definition of what employees' knowledge is and which its individual components are.

This paper's main purpose is therefore to present and discuss the main knowledge dimensions, to analyse the employees' knowledge in Slovenian SMEs, to theoretically develop a concept and measures for the main dimensions and, finally, to test the resulting multi-dimensional knowledge construct by using data from Slovenian SMEs. The key contribution of the study is the multidimensional knowledge construct, which can be usable especially for researchers, entrepreneurs and SME managers.

The paper is structured in five sections. The next section presents the theoretical framework on which the empirical analysis is based. The main focus is on the literature describing the dimensions of knowledge and the importance of employees' knowledge sources. In the second part, three hypotheses are developed, which are later empirically tested. The third section describes the methodology used, including the description of variables and measurements, data collection process, sample description and data analysis. The fourth section is dedicated to presenting the empirical findings together with a graphic presentation of the structural model. The results are summarized and the main findings discussed in the fifth section. The paper ends with conclusions and references.

\section{Theoretical background on knowledge in firms}

In the future, the economy will be based on knowledge, and business entities will need to become creators and managers of knowledge.

Several forms of knowledge exist in the organizations. Knowledge may be explicit or implicit (tacit) knowledge. Between these forms, several important differences exist. Explicit knowledge can be coded and summarized. It can even be stored and exchanged between persons (Popper 1972). It includes formal theoretical knowledge, which can be found in the form of databases, manuals, instructions and the like; objective knowledge, which can be put into words, or displayed otherwise (symbols, diagrams, symbols), as also knowledge to be formatted in a way that allow efficient transfer. It can be found in people and in various databases as well (Pučko 1998; Hitt et al. 2000; Kubr 2002). Contrary to explicit knowledge, tacit knowledge is more intuitive and difficult to transfer. This is the personal knowledge of people that is not codified and it is difficult to describe. It is in the minds of individuals and it can be acquired by the experience. In 
the consciousness of individual, there is much more tacit knowledge than could be expressed in documents or databases (Badaracco 1991; Nonaka et al. 2000).

In their studies about human resource management, Peters and Waterman (1982) emphasized the importance of human factors such as values, perspectives, commitments, symbols and opinions. Sveiby (1997) said that knowledge is the basis for everything, and everything in fact is knowledge. Before knowledge is characterized as one of the most important resources of an organization, we must imagine the organization as a learning organization and as such, based on knowledge.

When we talk about knowledge as the main source of value creation in the company, it means that we have started to treat knowledge as capital.

Knowledge as capital brings economic benefits to its owner, and such knowledge becomes a value fund. In defining knowledge as a form of capital, investment in knowledge should be emphasized. In fact, these investments increase the stock of existing knowledge and create a source of future income (Kešeljević 2004). Firms should identify and bring to full development their knowledge resources with the aim of strengthening or retaining their competitiveness, and improving their performance (Prahalad, Hamel 1990; Ruzzier, Antončič 2007). The result of investment is the creation of new human capital that cannot be separated from individuals.

\subsection{The importance of employees' knowledge}

The need for understanding the role of employees is not a new phenomenon. The role of other entrepreneurial resources is changing; the importance of financial capital is decreasing, while human capital is becoming increasingly important. Employees, as carriers of knowledge, emotions, skills, experience and values, are the most important source of competitive advantage and, consequently, of business performance (Tomažič 2003).

Human capital can be treated according to where it is most important (Dakhli, De Clerco 2004):

- human capital that is specific to an enterprise (Firm-specific Human Capital) covers knowledge that has a particular value only within the company. This type of human capital usually does not provide significant advantages for the company over its competitors;

- human capital that is specific for a particular industry (Industry-specific Human Capital) comprises the knowledge that is acquired by experience in their industry. This type of human capital plays an important role in the innovation design; usually it is held only by professionals in the sector;

- human capital that is specific for the individual (Individual-specific Human Capital), comprises the skills that can be used in various companies and industries. These are general managerial and entrepreneurial skills, education, experience and seniority, and skills acquired by professional training.

In their study, Herrmann and Peine (2011) were interested whether specific (qualifications that employees can use only within one single firm) or generic skills (qualifications that employees can use in all firms requiring certain business functions) are more important for facilitating innovation strategies. 
The entirety of human capital is held by employees. The aim of management is to pass human capital in the form of employees' special skills on to a network of many people, where it is fertilized and transferred to the ownership of the company. The value that the individual in the company creates to a certain extent comes back to him/her in the form of payment, and partly remains in the organisation as return on capital. According to Robert K. Eliot (Stewart 2003), the essence of the profits of companies is in people who, in cooperation with each other, create more than they could create separately. This happens mainly due to the transfer of knowledge from one to another, and its subsequent growth through new ideas.

Human capital is a part of the individual (Nonaka, Takeuchi 1995) and it particularly comprises knowledge gained by training and experience. Since, in addition to social capital, human capital is the most important factor in business (Anderson et al. 2002), it is understandable that human capital can be found in varying degrees, and its effects on the growth of the company have been studied by a number of researchers (Watts et al. 1998; Johannisson 1999; Cope, Watts 2000; Edelman et al. 2001; Honig 2001; Praag, Wit 2001; Piazza-Georgi 2002; Argyris 2002; Baron, Markman 2003). In addition to the knowledge and skills, some authors include in it a desire to succeed, the inherent properties of the individual intelligence and perceived self-efficacy in the chosen field of action (H. L. Dreyfus, S. E. Dreyfus 1986).

From the organizational point of view, human capital is a combination of knowledge, skills, and innovation and employee competencies in the company to execute the tasks (Edvinsson, Malone 1997). Human capital is the combination of results from individual investment in education and learning (Becker 1964). Davidsson and Honig (2003) also considered the acquisition of education, the attending of business school and years of work experience as parts of human capital.

Roos et al. (2000) declare human capital as (1) capabilities (composed of knowledge and skills), (2) relations (the attitude to work), and (3) intellectual flexibility (the ability of employees to use their knowledge in different situations and the ability to convert ideas into finished products or services).

Such an environment can no longer be defined as stable. Organisations are continuously transforming and changing. This is the reason they have to become willing to learn. Organisations should develop in "learning systems" that are capable of bringing about their own continuing transformation. Schön (1973) with human capital is being developed through flows of knowledge (Nemec Rudež, Mihalič 2007).

There are no universal ways of defining and measuring employees' knowledge in companies. In the existing studies, employees' knowledge is defined as a part or a component of the company's intellectual capital. It combines capabilities, i.e. the competences, work attitudes and innovation capabilities of individuals. Each of these components can be further divided. Knowledge is the sum of experience and heritage of social knowledge or of individual knowledge; it includes science, arts, religion, myths and magic (Wierzbicki 2007). Popper (1972) defined a new three-part knowledge framework, i.e. the world of ideas, knowledge, and arts. 
Many researchers have examined the importance of employees' knowledge (Lawler et al. 1998; Martocchio, Baldwin 1997; Salas, Cannon-Bowers 2001). Knowledge is indisputably the most important resource for any organization to acquire, and emerging companies always struggle to accumulate it as they mature (Bryant, Allen 2009). A firm's performance is conditional and dependent on employees' collective attitudes and motivation, behaviour, and human capital, including knowledge and competences (Tharenou et al. 2007). A company is more successful if its employees learn quickly, and implement and apply the acquired knowledge faster than their competition's employees. In view of the ever more pronounced shift from lifelong employment to lifelong employability, employees must see to it that their knowledge is sufficiently updated. A company must be capable of improving its existing skills as well as mastering new ones with a view to gaining or maintaining competitive advantage. Employees can and should take advantage of their potentially greater level of knowledge by engaging in work practices that lead to desired work outcomes (Werbel, Balkin 2010) and to desired firm performance.

Managers must ensure that there is a good fit between employees' skills, needs, and values when assigning different tasks to employees. In the engagement stage, the primary focus should be on identifying and providing employees with appropriate knowledge and other resources that will enable them to perform in the firm and contribute to its performance (Gruman, Saks 2010).

Knowledge is in the centre of interest in many recent researches on innovation and firm performance (Cantner et al. 2011; Roper, Arvanitis 2012; Chen, Huang 2009). Knowledge is the crucial element in the process of generating innovation. It has sufficient value to be managed as an asset; it requires special attention and firms should invest in employees, in their knowledge and learning (Cantner et al. 2011; Frenz, Ietto-Gillies 2009; Santos-Vijande et al. 2012; Ellinger et al. 2012). As employees are the carriers of knowledge and consequently they are a primary source of competitive advantage of the firm, it is important that they are motivated properly with the aim of ensuring the employees' positive work attitudes and outcomes (Chiang, Birtch 2010; Wang et al. 2011).

\subsection{Measuring knowledge}

Knowledge is often defined as a mix of understanding, interpretation and information. It is one of the characteristic of humans that affects their behaviour. The knowledge of an individual is formed by processing and anchoring in the brain whatever has been detected, i.e. the information obtained in the process of learning. Joia (2000) said that knowledge is intuitive, so it is difficult to define. Knowledge is the conscious or unconscious ability to act. The emphasis is placed on the element of action, because knowledge can be demonstrated only in performance effects. Specifically, we have to mention implicit knowledge as the personal knowledge of individuals based on their expectations, values and senses (Rodriguez Perez, Ordoñez de Pablos 2003).

Obviously, the knowledge of individuals is made up of their skills, experiences and values. It is demonstrated by their actions and abilities to solve problems. The definition of knowledge is therefore dynamic and is different from usual definitions. For 
understanding knowledge within the organization, there are three dimensions that are particularly relevant. The first dimension defines the level of knowledge, namely knowledge at individual, at group or at an overall organizational level (Huysman 2000). The second dimension distinguishes between explicit (formal, systemic and codified) and tacit (highly personal, specific and difficult-to-evaluate) knowledge (Nonaka 1994). The third dimension is a very valuable form: practical knowledge (Argyris 1993).

Knowledge must be separated from information and data. These dimensions are often unclear and mixed together. Although interrelated, they differ mainly on how they can be obtained or used (Tobin 1998). Data are the lowest level; these are numbers, symbols, words and everything detected by observation. When we realize that certain data would be of interest to us or our organization, they then become information. It depends on our perception whether the information can be defined as meaningful and useful or not. When the information is used and analysed, we add to it some significance and this is how we in fact expand and develop skills. Knowledge can bring benefits to the organization only after we are able to use it. The application of knowledge enables us to gain wisdom. This is the ability to connect knowledge with our previous experience and intuition. With wisdom, we can express opinions and use the knowledge to achieve desired objectives (Bierly et al. 2000).

Knowledge is difficult to measure. If we consider information as a dimension of the knowledge that forms part of an organization's capital, we can financially evaluate information and present its value in financial reports, like the value of other assets of an organization. One such approach is HRA (Human Resource Accounting), which was applied as early as several decades ago in a desire to determine and measure the value of employees and their knowledge with a view to establishing a more efficient managerial decision-making process (Sackmann et al. 1989). The following authors studied knowledge measurement: Zambon (2002) defined different knowledge evaluation methods; Lev (1999) developed a method for identifying the profitability of knowledge capital (Knowledge Capital Earnings) with a view to presenting the effects of investments in knowledge on financial performance; Kaplan and Norton (2000) developed a method of balanced indicators (Balance Scorecard, BSC) with four aspects of performance indicators (financial aspect, transactions with customers, the aspect of internal business processes, and the growth and learning aspect); the Skandia Navigator Model (Edvinsson, Malone 1997) was developed in Skandia, a Swedish company, and is composed of the financial and non-financial parts of the company's value.

\section{Toward the research hypotheses}

The purpose of the study was to clarify different determinants of the employees' knowledge, with the aim of developing the employees' knowledge model. The empirical analysis estimates the relationships in the structure of employees' knowledge model using data collected through questionnaires, completed by 173 firms. We identified three dimensions of employees' knowledge in the studied companies: employees' competences, employees' attitudes towards work, and employees' innovation capabilities. 
These dimensions were measured with several variables, among others: employees' qualification (Sveiby 1997; Kaplan, Norton 2000), staff recruitment, staff training, reward of employees for learning (Sveiby 1997; Kaplan, Norton 2000), employee experience variables, such as personnel egress, years of experience and share of permanently employed staff (Edvinsson, Malone 1997; Sveiby 1997; Stewart 2003). We have taken the variables for the measurement of employees' attitude from the Bontis criteria (Bontis 2002), Edvinsson and Malone (1997), Kaplan and Norton (2000). Innovation measurement was addressed by Stewart (2003), Roos et al. (2000), Kaplan and Norton (2000). In our study, we were particularly interested in developing the employees' knowledge model. Therefore, we have formulated the following hypothesis:

H1: The employees' knowledge model is a multidimensional construct.

H1a: The employee's competencies dimension is a consistent dimension in the employees' knowledge model.

H1b: The work attitude dimension is a consistent dimension in the employees' knowledge model.

H1c: The innovation capabilities dimension is a consistent dimension in the employees' knowledge model.

\section{Methodology}

The methodology is discussed in terms of the description of variables and measurement, data collection process, sample description and data analysis. Based on the aim of the research and the developed hypotheses, the conceptual employees' knowledge model was empirically verified on the sample of Slovenian small and medium enterprises.

\subsection{Variables and measurement}

Based on the literature review, interviews with human resource managers, and work with a pilot group, a questionnaire was designed, destined for directors/mangers of the firms. Variables were measured through scales previously tested and developed by a pilot group and were related to knowledge of employees, therefore to their capabilities, i.e. competences (education level, skills, and work experience), work attitude and innovation capabilities.

Data for this study were collected through printed questionnaires, distributed via mail. The basic characteristics of the questionnaires received were compared to those of the entire population to determine the consistency of the sample population. After undergoing the $\chi^{2}$ test under a level of significance at $5 \%$ the result showed that for the basic characteristic of business types as also business branch between the two groups had no marked difference, indicating questionnaires retrieved were representative of the population being studied. The questionnaire design was developed in accordance with previous research. Through 3 interviews of scholars and representatives of SMEs, and based on the opinions of experts, the research structure and variables included in the questionnaires were adapted in order to improve the content validity of the questionnaire. 


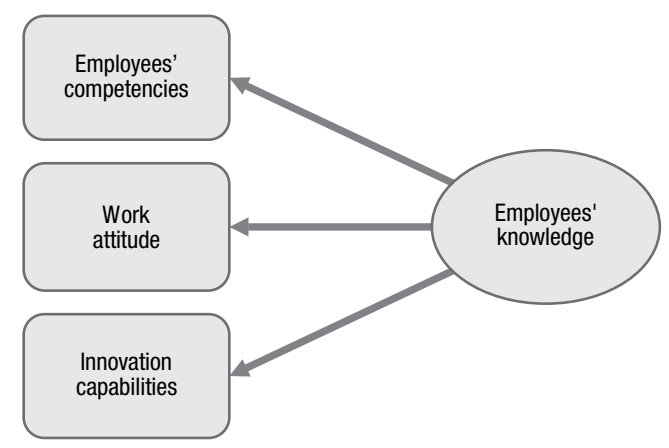

Fig. 1. Conceptual framework

Competences of employees were measured with 19 items, work attitude with 7 items and intellectual flexibility with 4 items. Respondents were asked to indicate (on a 5-point Likert-type scale ranging from "very non truthful" to "very truthful") how truthful were the statements on employees' knowledge.

Control variables data were collected about the relevant industry of the firm, firm age, firm size and firm disposition.

Our conceptual framework is visualised in Figure 1.

\subsection{Data collection process and sample description}

For data collection we used a questionnaire that was pre-tested. The questionnaire contained questions which provided the basic data on employees' knowledge and information about the firm. The target population were firms with 10 to 250 employees. The source of all business entities was the Ibon-Business Register of Slovenia. The sample was selected by random sampling, where we used the computer package SPSS and a 25 percent random selection. The final representative sample included 1355 companies (small and medium-sized). The majority of firms, 43 or $25.14 \%$ operated in the production industry: of these 5 or $2.92 \%$ produce consumable goods, whereas 38 or $22.22 \%$ of them produce industrial goods. There were 35 or $20.47 \%$ companies which were active in retailing and wholesale. 30 or $17.54 \%$ of firms were active in civil engineering, and 12 or $7.02 \%$ of companies were active in consultancy or similar business services. 10 or $5.85 \%$ of companies were from transport and public services, 9 or $5.26 \%$ of companies were from the engineering sector, research and development. All other companies were active in consumer services, banking, investments, insurance or similar services. The majority of companies have between 11 and 50 employees. There are 122 or $69.51 \%$ of such companies.

\section{Findings}

Further, we were interested in employees' skills (see Table 1), their capacity for innovative thinking and their attitude to work as these are the dimensions of our model. To this end, the survey estimated 28 claims, which in theory explain the dimensions. The 
Table 1. Employees' skills

\begin{tabular}{|c|c|c|c|c|}
\hline Skills & Mean & SD & Skew & Kurt \\
\hline Our employees have at least 2 years of work experience & 4.47 & 0.96 & -2.13 & 4.34 \\
\hline Our employees have worked in our firm for at least two years & 4.31 & 1.01 & -1.74 & 2.85 \\
\hline Our employees hold proper qualifications for their job & 4.08 & 0.75 & -0.80 & 1.34 \\
\hline $\begin{array}{l}\text { Our employees possess adequate technical knowledge to } \\
\text { perform their tasks }\end{array}$ & 3.94 & 0.762 & -0.62 & 0.87 \\
\hline $\begin{array}{l}\text { Our employees have a positive attitude to the company's } \\
\text { development }\end{array}$ & 3.87 & 0.77 & -0.39 & 0.33 \\
\hline Our workers are appropriately rewarded for their work & 3.84 & 0.84 & -0.17 & -0.45 \\
\hline $\begin{array}{l}\text { Our employees are always trying to offer customers } \\
\text { the best service }\end{array}$ & 3.84 & 0.86 & -0.29 & -0.63 \\
\hline Our employees are proud to work in our company & 3.83 & 0.74 & 0.02 & -0.65 \\
\hline $\begin{array}{l}\text { Our company is able to successfully adapt itself to changes } \\
\text { in the market }\end{array}$ & 3.78 & 0.84 & -0.41 & 0.00 \\
\hline Our employees perform their work and tasks with diligence & 3.76 & 0.77 & -0.32 & 0.25 \\
\hline There are mostly permanent workers & 3.65 & 1.50 & -0.75 & -0.93 \\
\hline Our employees share ideas & 3.65 & 0.87 & -0.17 & -0.63 \\
\hline Our employees are committed to our company & 3.62 & 0.85 & -0.15 & -0.05 \\
\hline Our company is successful in recruiting good workers & 3.47 & 0.87 & -0.22 & -0.20 \\
\hline Our employees are creative workers & 3.46 & 0.88 & -0.29 & 0.16 \\
\hline $\begin{array}{l}\text { Our employees regard their employment in our firm } \\
\text { as a challenge }\end{array}$ & 3.44 & 0.90 & -0.18 & 0.06 \\
\hline Our employees are creative workers & 3.46 & 0.88 & -0.29 & 0.16 \\
\hline Our employees are highly productive & 3.40 & 0.83 & -0.43 & 0.76 \\
\hline Our managers have sufficient knowledge in management & 3.39 & 0.92 & -0.44 & 0.13 \\
\hline $\begin{array}{l}\text { Our employees possess adequate knowledge in the field } \\
\text { of product/service development to perform their tasks }\end{array}$ & 3.36 & 0.92 & -0.27 & -0.03 \\
\hline Our company has an effective promotion system & 3.25 & 1.07 & -0.41 & -0.39 \\
\hline Our employees are brimming with ideas & 3.24 & 0.96 & -0.07 & -0.25 \\
\hline $\begin{array}{l}\text { As continual learners, our employees keep deepening } \\
\text { their knowledge }\end{array}$ & 3.19 & 1.03 & 0.04 & -0.54 \\
\hline $\begin{array}{l}\text { Our employees are satisfied with the quality } \\
\text { of in-house training }\end{array}$ & 3.18 & 0.99 & -0.09 & -0.14 \\
\hline We successfully imitate the innovation from competitors & 3.18 & 1.04 & -0.28 & -0.24 \\
\hline Our employees learn a lot from our clients and suppliers & 3.13 & 1.09 & -0.24 & -0.37 \\
\hline $\begin{array}{l}\text { Our employees possess adequate marketing knowledge } \\
\text { to perform their tasks }\end{array}$ & 2.95 & 0.92 & -0.45 & 0.03 \\
\hline Our employees keep discovering new markets & 2.80 & 1.06 & -0.03 & -0.73 \\
\hline We have a lot of seasonal workers & 1.56 & 1.04 & 1.82 & 2.27 \\
\hline
\end{tabular}

Notes: Mean for the scale from 1 to 5 (1 very non true, 5 very true); SE - standard error; Skew Skewness, Kurt - Kurtosis, SD - standard deviation, $\mathrm{n}=173$. 
statement that was estimated as truest was that "employees have at least two years of work experience" (score 4.471 on a scale of 1 to 5), only slightly less true was considered the argument that "our employees have worked in our firm for at least two years" (estimated at 4.318 on a scale of 1 to 5), and the argument that "our employees hold proper qualifications for their job" (score 4.081 on a scale of 1 to 5). Assessed as a most false were the statements "we have a lot of seasonal workers" (score 1.563 on a scale of 1 to 5), "our employees keep discovering new markets" (score 2.802 on a scale of 1 to 5), and the argument that "our employees possess adequate marketing knowledge to perform their tasks" (score 2.959 on a scale of 1 to 5).

Additionally we wanted to know how often employees attend training courses with specific content areas. Questions were divided into four sections, for four different levels of personnel structure. Questions were separated into groups, i.e. for managers, for professionals (lawyers, accountants, etc), for the administration, and finally for executants. We used a scale of 1 to 5, where 1 meant "not participating at all", and 5 meant "many participations", to ask for the frequency of participatory training in the areas of (1) Leadership, communication and relations, (2) Planning and organizing, (3) Specific professional skills (finance and accounting, law, technology, personnel), (4) Software tools, (5) Languages, (6) Health and safety at work, ecology and fire safety, and (7) Teamwork. The frequencies of trainings are presented in Table 2.

For all levels of personnel structure it is significant that the staff mostly participates in training on safety and health, ecology and fire safety (for three groups the frequency of such training is in the first place, for one group in the second). Managers often (an average of 3.105 on the scale of 1 to 5) attend training sessions for specific skills (finance and accounting, law, technology, personnel, etc.) and training in the field of planning and organizing work (an average of 2.699 on the scale of 1 to 5). The managers least often attend the training in the field of language (an average of 2.353 on a scale of 1 to 5 ) and software tools (an average of 2.618 on a scale of 1 to 5).

The second group of questions was designed to assess the frequency of training for professionals (lawyers, accountants ...); 16 respondents did not answer and explained that they hire such professionals from outside. Otherwise, staff of this level often attend training sessions for specific professional skills (an average of 3.605 on a scale of 1 to 5) and training in health and safety at work, ecology and fire safety (an average of 3.102 on a scale of 1 to 5). Less frequently, they attend training in language (an average of 2.293 on a scale of 1 to 5) and in leadership, communication and relations (an average of 2.459 on a scale of 1 to 5 ).

The administration staff most often attend training sessions on health and safety at work, ecology and fire safety (an average of 3.006 on a scale of 1 to 5) and training in specific professional skills (an average of 2.788 on a scale of 1 to 5 ).

They do not participate much in training in the field of language (an average of 2.292 on the scale of 1 to 5) and in leadership, communication and relations (an average of 2.429 on the scale of 1 to 5). Also for this level of staff 12 companies did not respond, which in turn means that they outsource these workers. 
Table 2. The frequency of trainings - mean and standard deviation

\begin{tabular}{|c|c|c|c|}
\hline Staff & Training areas & Mean & $\mathrm{SD}$ \\
\hline \multirow[t]{7}{*}{ Managers } & Health and safety at work, ecology and fire safety & 3.448 & 1.210 \\
\hline & $\begin{array}{l}\text { Specific professional skills (finance and accounting, law, } \\
\text { technology, personnel) }\end{array}$ & 3.105 & 1.219 \\
\hline & Planning and organizing & 2.699 & 1.167 \\
\hline & Teamwork & 2.686 & 1.254 \\
\hline & Leadership, communication and relations & 2.618 & 1.208 \\
\hline & Software tools & 2.618 & 1.246 \\
\hline & Languages & 2.353 & 1.175 \\
\hline \multirow{7}{*}{$\begin{array}{l}\text { Professionals } \\
\text { (lawyers, } \\
\text { accountants) }\end{array}$} & $\begin{array}{l}\text { Specific professional skills (finance and accounting, law, } \\
\text { technology, personnel) }\end{array}$ & 3.605 & 1.275 \\
\hline & Health and safety at work, ecology and fire safety & 3.102 & 1.388 \\
\hline & Software tools & 2.673 & 1.261 \\
\hline & Planning and organizing & 2.635 & 1.186 \\
\hline & Teamwork & 2.522 & 1.233 \\
\hline & Leadership, communication and relations & 2.459 & 1.201 \\
\hline & Languages & 2.293 & 1.189 \\
\hline \multirow{7}{*}{$\begin{array}{l}\text { Administration } \\
\text { staff }\end{array}$} & Health and safety at work, ecology and fire safety & 3.006 & 1.362 \\
\hline & $\begin{array}{l}\text { Specific professional skills (finance and accounting, law, } \\
\text { technology, personnel) }\end{array}$ & 2.788 & 1.241 \\
\hline & Software tools & 2.627 & 1.274 \\
\hline & Teamwork & 2.506 & 1.313 \\
\hline & Planning and organizing & 2.450 & 1.212 \\
\hline & Leadership, communication and relations & 2.429 & 1.273 \\
\hline & Languages & 2.292 & 1.202 \\
\hline \multirow[t]{6}{*}{ Executives } & Health and safety at work, ecology and fire safety & 3.341 & 1.392 \\
\hline & $\begin{array}{l}\text { Specific professional skills (finance and accounting, law, } \\
\text { technology, personnel) }\end{array}$ & 2.279 & 1.286 \\
\hline & Software tools & 2.244 & 1.236 \\
\hline & Planning and organizing & 2.238 & 1.190 \\
\hline & Leadership, communication and relations & 2.196 & 1.200 \\
\hline & Languages & 1.814 & 1.016 \\
\hline
\end{tabular}

The executive workers most often attend training sessions and safety at work, ecology and fire safety (an average of 3341 on the scale of 1 to 5) and training and for specific professional skills (an average of 2279 on the scale of 1 to 5). They least often attend training in languages (an average of 1814 on the scale of 1 to 5) and in leadership, communication and relations (an average of 2196 on the scale of 1 to 5). 
The explorative analysis was carried out at the beginning. The initial number of selected dimensions was consistent with our expectations based on theory. The following basic dimensions were anticipated for the dimension of employees' knowledge: (1) competences, (2) attitude, and (3) innovation capabilities. The postulated construct of employees' knowledge has not been empirically backed up, thus possible uncertainties were expected, which meant that the number of dimensions could be smaller or larger than the number identified on the basis of the literature review. When deciding on the number of factors we took into account own value, the share of explained variance and scree plot. The scree plot shows that the possible number of factors is between 3 and 6 . We checked all the solutions, with the most suitable solution being the one with five factors. These five factors explain the $64.46 \%$ of variance, which is a satisfactory result. Factors that could not be explained appeared in other analyses. By taking into account the communality of individual variables we decided which variables should be kept. The KMO measure had the value of 0.872 for all variables, which represents a perfect assessment of suitability of the chosen variables. The five dimensions of employees' knowledge (23 variables), which were selected through the exploratory factor analysis, are shown in Table 3.

In view of our expectations developed in accordance with the above-mentioned theoretical concepts, the study revealed two sub-dimensions more than expected. Instead of the following three sub-dimensions: (1) competences, (2) attitude, and (3) innovation capabilities, the research brought to light five factors, which, however, can be logically explained. Factor F1 can justifiably be called innovation capabilities and willingness to learn. Factor F2 is called attitude. Factor F3 is termed job qualification. Factor F4 covers two variables, both related to employee education, and is therefore labelled formal education. Factor F5 covers two variables related to work experience, and hence is called work experience.

\subsection{Employees' knowledge construct}

The performance of exploratory factor analysis with SPSS revealed that the employee knowledge dimension consists of the following five sub-dimensions: innovation capabilities and willingness to learn, attitude to work, job qualification, formal education and work experience. For each factor, confirmatory factor analysis was performed using the EQS package.

\section{Innovation capabilities and willingness to learn}

Exploratory factor analysis established that the sub-dimension of innovation capabilities and willingness to learn can be explained with 10 variables. Confirmatory factor analysis confirmed the validity of variables for the said sub-dimension. All coefficients proved positive, high (from 0.54 to 0.82 ) and statistically significant. This sub-dimension demonstrated appropriate reliability (Cronbach alfa 0.88 , which is a value above the threshold of 0.80) and convergence in the sense of coefficients (they were all positive, high and statistically significant), with the model suitability indices (CFI, NFI, RHO, RMSEA, SRMR) having shown satisfactory values (CFI $=0.95$; NFI $=0.93$; $\operatorname{SRMR}=0.14 ; \mathrm{RMSEA}=0.09 ; \mathrm{RHO}=0.90$; construct internal consistency $=0.91$ ). 
Table 3. Factors and weights of individual variables for the dimension of employees' knowledge

\begin{tabular}{|c|c|c|c|c|c|}
\hline Variable & F1 & $\mathrm{F} 2$ & $\mathrm{~F} 3$ & F4 & F5 \\
\hline Our employees keep discovering new markets & 0.743 & & & & \\
\hline $\begin{array}{l}\text { Our employees regard their employment in our company } \\
\text { as a challenge }\end{array}$ & 0.641 & & & & \\
\hline $\begin{array}{l}\text { Our employees possess adequate marketing knowledge } \\
\text { to perform their tasks }\end{array}$ & 0.586 & & & & \\
\hline Our employees are brimming with ideas & 0.581 & & & & \\
\hline Our company has an effective promotion system & 0.574 & & & & \\
\hline $\begin{array}{l}\text { Our company is able to successfully adapt itself to } \\
\text { changes in the market }\end{array}$ & 0.535 & & & & \\
\hline Our employees learn a lot from our clients and suppliers & 0.515 & & & & \\
\hline $\begin{array}{l}\text { As continual learners, our employees keep deepening } \\
\text { their knowledge }\end{array}$ & 0.510 & & & & \\
\hline $\begin{array}{l}\text { Our employees are satisfied with the quality of in-house } \\
\text { training }\end{array}$ & 0.498 & & & & \\
\hline Our employees are creative workers & 0.495 & & & & \\
\hline Our employees are proud to work in our company & & 0.805 & & & \\
\hline $\begin{array}{l}\text { Our employees have a positive attitude to the company's } \\
\text { development }\end{array}$ & & 0.748 & & & \\
\hline Our employees share ideas & & 0.633 & & & \\
\hline Our employees are committed to our company & & 0.546 & & & \\
\hline $\begin{array}{l}\text { Our employees perform their work and tasks with } \\
\text { diligence }\end{array}$ & & 0.529 & & & \\
\hline Our employees hold proper qualifications for their job & & & 0.795 & & \\
\hline $\begin{array}{l}\text { Our employees possess adequate technical knowledge } \\
\text { to perform their tasks }\end{array}$ & & & 0.771 & & \\
\hline $\begin{array}{l}\text { Our employees possess adequate knowledge in the field } \\
\text { of product/service development to perform their tasks }\end{array}$ & & & 0.551 & & \\
\hline Our employees are highly productive & & & 0.398 & & \\
\hline $\begin{array}{l}\text { What is the prevailing level of education among your } \\
\text { employees? }\end{array}$ & & & & 0.876 & \\
\hline $\begin{array}{l}\text { What percentage of your employees has a BA or BSc } \\
\text { or a higher degree? }\end{array}$ & & & & 0.857 & \\
\hline $\begin{array}{l}\text { Our employees have worked in our company for at least } \\
\text { two years. }\end{array}$ & & & & & 0.959 \\
\hline $\begin{array}{l}\text { Our employees have at least } 2 \text { years of work experience } \\
\text { (all together). }\end{array}$ & & & & & 0.757 \\
\hline
\end{tabular}




\section{Attitude}

Exploratory factor analysis established that the sub-dimension of attitude can be explained with 5 variables. Confirmatory factor analysis confirmed the validity of variables for the said sub-dimension. All coefficients proved positive, high (from 0.56 to 0.88 ) and statistically significant. This sub-dimension demonstrated appropriate reliability (Cronbach alfa 0.85 , which is a value above the threshold of 0.80 ) and convergence in the sense of coefficients (they were all positive, high and statistically significant), with the model suitability indices (CFI, NFI, RHO, RMSEA, SRMR) having shown satisfactory values $(\mathrm{CFI} 0.89 ; \mathrm{NFI}=0.87$; $\mathrm{SRMR}=0.69 ; \mathrm{RMSEA}=0.20 ; \mathrm{RHO}=0.86$; construct internal consistency $=0.90)$.

\section{Job qualification}

Exploratory factor analysis established that the sub-dimension of job qualification can be explained with 4 variables. Confirmatory factor analysis confirmed the validity of variables for the said sub-dimension. All coefficients proved positive, high (from 0.59 to 0.92 ) and statistically significant. This sub-dimension demonstrated appropriate reliability (Cronbach alfa 0.77 , which is a value above 0.70 and below 0.80 ) and convergence in the sense of coefficients (they were all positive, high and statistically significant), with the model suitability indices (CFI, NFI, RHO, RMSEA, SRMR) having shown satisfactory values $(\mathrm{CFI}=0.87$; $\mathrm{NFI}=0.86$; $\mathrm{SRMR}=0.69 ; \mathrm{RMSEA}=0.22 ; \mathrm{RHO}=$ 0.88 ; construct internal consistency $=0.92$ ).

\section{Formal education}

Exploratory factor analysis established that the sub-dimension of formal education can be explained with 2 variables. Confirmatory factor analysis confirmed the validity of variables for the said sub-dimension. All coefficients proved positive, high ( 0.85 do 0.95 ) and statistically significant. This sub-dimension demonstrated appropriate reliability (Cronbach alfa 0.89 , which is a value above the threshold of 0.80 ) and convergence in the sense of coefficients (they were all positive, high and statistically significant), other indices were not calculated because of too few variables $(\mathrm{RHO}=0.89$; construct internal consistency $=0.92$ ).

We proceed with an analysis of the dimension of employees' knowledge.

\section{Work experience}

Exploratory factor analysis established that the sub-dimension of work experience can be explained with 2 variables. Confirmatory factor analysis confirmed the validity of variables for the said sub-dimension. All coefficients proved positive, high (from 0.76 to 0.99 ) and statistically significant. This sub-dimension demonstrated appropriate reliability (Cronbach alfa 0.861 , which is a value above the threshold of 0.80 ) and convergence in the sense of coefficients (they were all positive, high and statistically significant), other indices were not calculated because of too few variables $(\mathrm{RHO}=0.88$; construct internal consistency $=0.98$ ).

Statistical information about the internal consistency of each sub-dimension (Cronbach alfa) and convergence (indices of model suitability) is shown in Table 4. The employees' 
Table 4. The employees' knowledge construct

\begin{tabular}{|c|c|c|c|c|c|c|c|}
\hline & Dimensions & $\begin{array}{l}\text { Inn. cap. } \\
\text { \& will. }\end{array}$ & Attitude & Job qual. & $\begin{array}{l}\text { Formal. } \\
\text { education }\end{array}$ & $\begin{array}{l}\text { Work } \\
\text { exper. }\end{array}$ & All \\
\hline & Variables & 10 & 5 & 4 & 2 & 2 & 23 \\
\hline & Coefficients & $\begin{array}{c}0.544 \text { to } \\
0.817\end{array}$ & $\begin{array}{c}0.562 \text { to } \\
0.886\end{array}$ & $\begin{array}{c}0.592 \text { to } \\
0.918\end{array}$ & $\begin{array}{c}0.850 \text { to } \\
0.951\end{array}$ & $\begin{array}{c}0.764 \text { to } \\
0.991\end{array}$ & $\begin{array}{c}0.558 \text { to } \\
0.918\end{array}$ \\
\hline \multirow{4}{*}{ 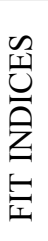 } & NFI & 0.93 & 0.87 & 0.86 & $*$ & $*$ & 0.92 \\
\hline & CFI & 0.95 & 0.89 & 0.87 & $*$ & $*$ & 0.97 \\
\hline & SRMR & 0.14 & 0.69 & 0.69 & $*$ & $*$ & 0.40 \\
\hline & RMSEA & 0.09 & 0.2 & 0.22 & $*$ & $*$ & 0.06 \\
\hline \multirow{3}{*}{ 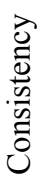 } & Cronbach alfa & 0.88 & 0.85 & 0.77 & 0.89 & 0.86 & 0.91 \\
\hline & RHO & 0.90 & 0.86 & 0.88 & 0.89 & 0.88 & 0.97 \\
\hline & Internal consistency & 0.91 & 0.90 & 0.92 & 0.92 & 0.98 & 0.93 \\
\hline
\end{tabular}

Note: * Because of there being only two items, the indices were not calculated.

knowledge dimension demonstrated appropriate reliability (Cronbach alfa 0.91 , which is a value above the threshold of 0.80) and convergence in the sense of coefficients (they were all positive, high and statistically significant), with the model suitability indices (CFI, NFI, RHO, RMSEA, SRMR) having shown satisfactory values.

Statistical information on each item is indicated in Table 5, the construct of employees' knowledge is indicated in Figure 2.

Table 5. Standardised coefficients

\begin{tabular}{lcc}
\hline \multicolumn{1}{c}{ Variables } & $\begin{array}{c}\text { Stand. } \\
\text { weights }\end{array}$ & T test \\
\hline What is the prevailing level of education among your employees? & 0.904 & fixed \\
\hline What percentage of your employees has a BA or BSc or a higher degree? & 0.907 & $12.433^{*}$ \\
\hline Our employees hold proper qualifications for their job & 0.901 & fixed \\
\hline $\begin{array}{l}\text { Our employees possess adequate technical knowledge to perform } \\
\text { their tasks }\end{array}$ & 0.918 & $19.226^{*}$ \\
\hline $\begin{array}{l}\text { Our employees possess adequate knowledge in the field of product/service } \\
\text { development to perform their tasks }\end{array}$ & 0.770 & $12.750^{*}$ \\
\hline Our employees have at least 2 years of work experience (altogether) & 0.910 & $11.973^{*}$ \\
\hline $\begin{array}{l}\text { Our employees have worked in our company for at least two years } \\
0.880\end{array}$ & fixed \\
\hline $\begin{array}{l}\text { Our employees are creative workers } \\
\text { Our employees possess adequate marketing knowledge to perform }\end{array}$ & 0.801 & $13.500^{*}$ \\
\hline \begin{tabular}{l} 
their tasks \\
\hline
\end{tabular} & & $10.714^{*}$ \\
\hline
\end{tabular}


End of Table 5

\begin{tabular}{lcc}
\hline \multicolumn{1}{c}{ Variables } & $\begin{array}{c}\text { Stand. } \\
\text { weights }\end{array}$ & T test \\
\hline Our employees are highly productive & 0.668 & $9.920^{*}$ \\
\hline As continual learners, our employees keep deepening their knowledge & 0.703 & $10.646^{*}$ \\
\hline Our employees are satisfied with the quality of in-house training & 0.607 & $8.529^{*}$ \\
\hline Our employees learn a lot from our clients and suppliers & 0.672 & $9.917^{*}$ \\
\hline Our employees share ideas & 0.859 & fixed \\
\hline Our employees are proud to work in our company & 0.872 & $16.815^{*}$ \\
\hline Our employees have a positive attitude to the company's development & 0.887 & $17.631^{*}$ \\
\hline Our employees perform their work and tasks with diligence & 0.773 & $12.812^{*}$ \\
\hline Our company has an effective promotion system & 0.558 & $7.592^{*}$ \\
\hline Our employees regard their employment in our company as a challenge & 0.862 & $15.847^{*}$ \\
\hline Our employees are committed to our company & 0.783 & $13.151^{*}$ \\
\hline Our company is able to successfully adapt itself to changes in the market & 0.727 & $11.261^{*}$ \\
\hline Our employees are brimmin with ideas & 0.847 & $15.206^{*}$ \\
\hline Our employees keep discovering new markets & 0.783 & fixed \\
\hline
\end{tabular}

Note: ${ }^{*} \mathrm{p}<0.05$.

Ranging from 0.36 to 0.86 , correlations between the sub-dimensions were statistically significant, with the exception of the one between the sub-dimensions of work experience and formal education that scored only 0.03 . However, such a low value was not at all surprising since there was no reason for the existence of a close correlation between the two sub-dimensions. Nevertheless, none of them was excluded as they both correlated strongly with the remaining three sub-dimensions, which indicated their convergence but not their redundancy. The highest correlation (0.86) was scored between the sub-dimensions of attitude to work on the one hand and innovation capabilities and willingness to learn on the other, which can be explained by the fact that those who have a positive attitude to their work are, naturally, willing to acquire additional knowledge and to channel their energy into innovative ideas and working techniques.

Table 6. Correlations among factors

\begin{tabular}{cccccc}
\hline Factor & F1 & F2 & F3 & F4 & F5 \\
\hline F1 & 1 & $0.862^{*}$ & $0.714^{*}$ & $0.506^{*}$ & $0.398^{*}$ \\
\hline F2 & $0.862^{*}$ & 1 & $0.764^{*}$ & $0.457^{*}$ & $0.402^{*}$ \\
\hline F3 & $0.714^{*}$ & $0.764^{*}$ & 1 & $0.361^{*}$ & $0.494^{*}$ \\
\hline F4 & $0.506^{*}$ & $0.457^{*}$ & $0.361^{*}$ & 1 & $0.028^{*}$ \\
\hline F5 & $0.398^{*}$ & $0.402^{*}$ & $0.494^{*}$ & $0.028^{*}$ & 1 \\
\hline
\end{tabular}

Note: $* \mathrm{p}<0.05$. 


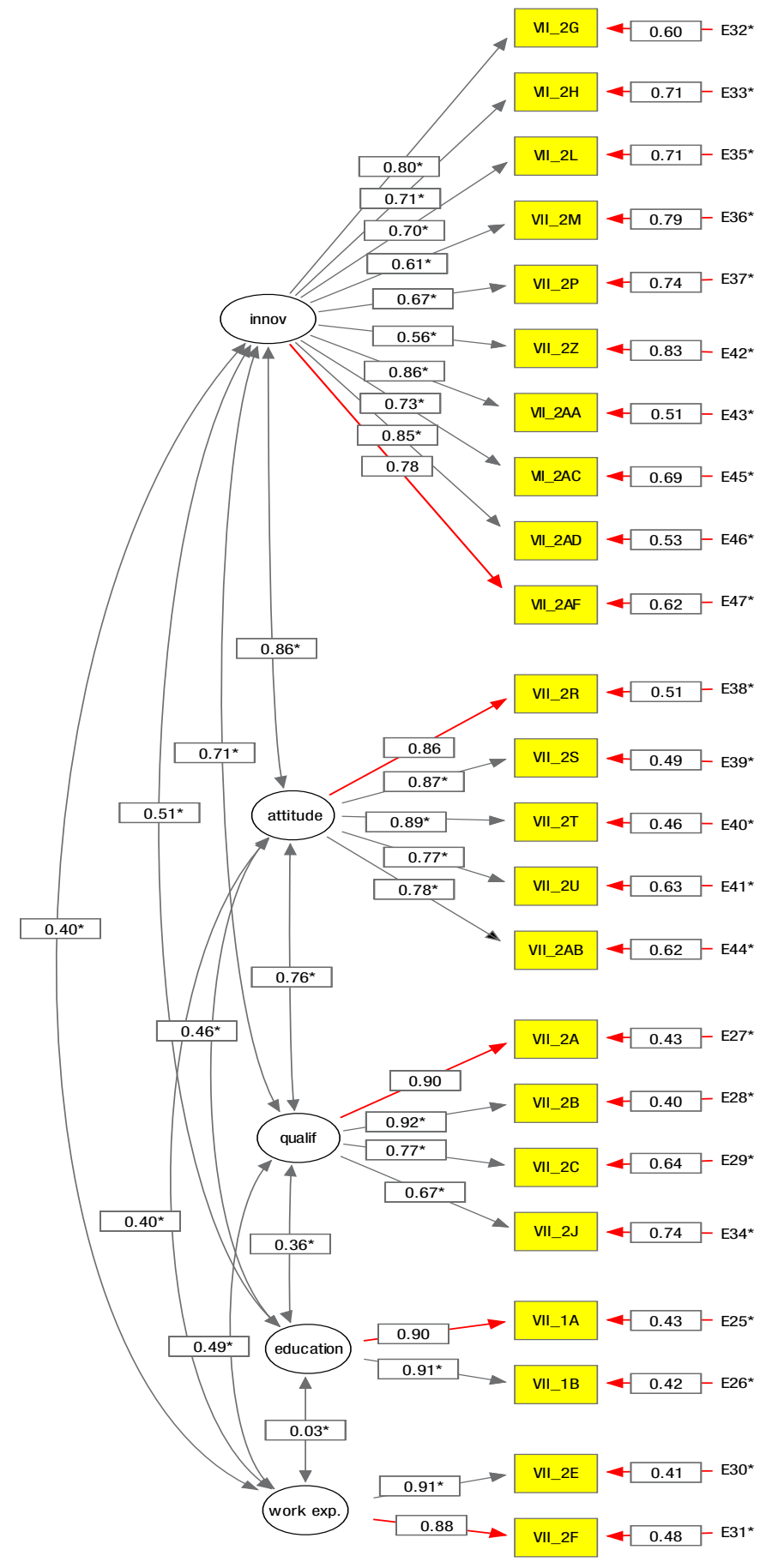

Fig. 2. Employees' knowledge construct (Standardised coefficients)

Notes: $\mathrm{CFI}=0.97 ; \mathrm{NFI}=0.92 ; \mathrm{SRMR}=0.40 ;$ RMSEA $=0.06 ;$ Cronbach alfa $=0.91$; $\mathrm{RHO}=0.97$. The correlations among factors are indicated in Table 6. 


\section{Discussions}

Factor analysis findings indicated a five dimensional structure of the employees' knowledge construct. The initial proposed model suggested 3 dimensions, i.e. (1) Employees' competencies, (2) Work attitude, and (3) Innovation capabilities; but by performing factor analysis we obtained 5 dimensions. These refer to: (1) Innovation capabilities and willingness to learn, (2) Attitude, (3) Job qualification, (4) Formal education and (5) Work experience. Therefore, our study developed an integrative multidimensional employees' knowledge construct, which incorporates its broader content aspects. Important elements in factor F1: innovation capabilities and willingness can be considered as the employees' capacity of discovering new markets, the employees dealing with their employment in the company as a challenge, possessing adequate marketing knowledge to perform the tasks, brimming with ideas, the existence of an effective promotion system and the company's ability to successfully adapt itself to changes in the market. In factor F2: attitude, we can find elements such as: employees being proud to work in the company, a positive attitude to the company's development, the willingness to share ideas, the commitment to the company and the employees' performance of the work and tasks with diligence. Factor F3: job qualification includes statements such as employees hold proper qualifications for their work place, they possess adequate technical knowledge to perform their tasks, and they possess adequate knowledge and are highly productive. Factor F4: formal education comprises the employees' level of education and a percentage of the employees with a BSc or a higher degree. The elements of factor F5: work experiences are the statements about work experience altogether and about the time of being employed in the company.

On the whole, we can confirm that employee's knowledge is a multidimensional construct. In accordance with the reviewed literature, we expected three dimensions; however, we have identified two additional dimensions, a total of five dimensions. Hypothesis 1 and sub-hypotheses $1 \mathrm{~b}$ are therefore entirely confirmed, while hypothesis $1 \mathrm{a}$ and $1 \mathrm{c}$ are confirmed just partially.

The five-dimensional employees' knowledge construct represents an important contribution to research and practice. Conclusions, implications and limitations are discussed in the next section.

\section{Conclusions}

Although this study has considerable strengths, it also has some limitations that need to be acknowledged. These are: (1) the above mentioned sample - we were limited to Slovenian companies, namely to Slovenian small and medium-sized companies; (2) questionnaire: factors were studied on the basis of data collected with a questionnaire, which used perceptual measures, which are subjective in nature but capture detailed information about the concept studied; (3) duration of the research: acquired data represent the situation in companies on a certain date (cross-sectional study design); (4) model: our model does not include all elements of employees' knowledge, but it can be considered relatively more complete than previous models, since it includes a higher 
number of dimensions. Despite these limitations this study yields important contributions and implications.

Based on the studied literature, it was concluded that the existing theoretical and applied research activities deal with the role of employees' knowledge. On the other hand, they do not analyse the importance of different employees' knowledge related variables, and also fail to mention their influence in SMEs.

The employees' knowledge model that was tested in this study can be seen as relatively robust. Results of this study can be generalized to some extent, because a variety of industries were included in the sample. This study has made a contribution by developing a model of the employees' knowledge in SMEs. The study also has important implications for researchers and practitioners. An important issue for researchers is the selection of an appropriate conceptual and measurement model. By modelling employees' knowledge by using multiple dimensions, a more complete and accurate approximation of the actual employees' knowledge structure can be achieved and empirically tested.

We have thus developed an employees' knowledge model in SME, tested it empirically on a sample of Slovenian small and medium-sized companies and thus proved its multidimensional character. For the purpose of the model design we have developed a model of the factors which constitute and measure employees' knowledge. In firm practice, dimensions of the employees' knowledge (Innovation capabilities and willingness to learn, attitude, job qualification, formal education and work experience) can have beneficial effects on the firm's performance. Firms with employees who nurture their knowledge and skills are more likely to have higher growth and profitability than organizations in which employees are lacking such characteristics. SMEs and their employees are those that are particularly critical for the economic development in Slovenian and other economies.

The findings of our study are not limited only to SMEs. The results are also relevant for large organizations. The key contribution is the development of a multidimensional model of employees' knowledge.

\section{References}

Anderson, C. L; Locker, L.; Nugent, R. 2002. Microcredit, social capital and common pool resources, World Development 30(1): 95-118. http://dx.doi.org/10.1016/S0305-750X(01)00096-1

Argyris, C. 1993. Knowledge for action. San Francisco: CA: Jossey-Bass. http://dx.doi.org/10.5465/AMLE.2002.8509400

Argyris, C. 2002. Double-loop learning, teaching, and research, Academy of Management Learning and Education 1(2): 206-218.

Badaracco, Jr. J. L. 1991. Alliances speed knowledge transfer, Strategy \& Leadership 19(2): 10-16.

Baron, A. R.; Markman, D. G. 2003. Beyond social capital: the role of entrepreneurs social competence in their financial success, Journal of Business Venturing 18(1): 41-60.

http://dx.doi.org/10.1016/S0883-9026(00)00069-0

Becker, G. S. 1964. Human capital. Chicago: University of Chicago Press. 
Belasco, J.; Stayer, R. 1994. Why empowerment doesn't empower: the bankruptcy of current paradigms, Business Horizons 37(2): 29-41.

Bierly, P. E.; Christens, E. W.; Kessler, E. H. 2000. Organisational learning, knowledge and wisdom, Journal of Organizational Change Management 13(6): 595-618.

http://dx.doi.org/10.1108/09534810010378605

Bontis, N. 2002. National intellectual capital development, intellectual capital, from potential to value creation, in Zbornik mednarodne konference o intelektualnem kapitalu, Portorož 6, 7 June, 2002. Ljubljana: Center za intelektualni capital.

Bryant, P. C.; Allen, D. G. 2009. Emerging organizations' characteristics as predictors of human capital employment mode: a theoretical perspective, Human Resource Management Review 19: 347-355. http://dx.doi.org/10.1016/j.hrmr.2008.12.002

Cantner, U.; Joel, K.; Schmidt, T. 2011. The effects of knowledge management on innovative success - an empirical analysis of German firms, Research Policy 40: 1453-1462.

http://dx.doi.org/10.1016/j.respol.2011.06.007

Chen, C. J.; Huang, J. W. 2009. Strategic human resource practices and innovation performance the mediating role of knowledge management capacity, Journal of Business Research 62: 104114. http://dx.doi.org/10.1016/j.jbusres.2007.11.016

Chiang, F. F. T.; Birtch, T. A. 2010. Pay for performance and work attitudes: the mediating role of employee-organization service value congruence, International Journal of Hospitality Management 29: 632-640. http://dx.doi.org/10.1016/j.ijhm.2009.11.005

Cope, J.; Watts, G. 2000. Learning by doing: an exploration of experience, critical incidents and reflection in entrepreneurial learning, International Journal of Entrepreneurial Behaviour \& Research 6(3): 104-124. http://dx.doi.org/10.1108/13552550010346208

Dakhli, M.; De Clerco, D. 2004. Human capital, social capital, and innovation: a multicountry study, Entrepreneurship \& Regional Development 6(2): 107-128.

http://dx.doi.org/10.1080/08985620410001677835

Davidsson, P.; Honig, B. 2003. The role of social and human capital among nascent enterpreneurship, Journal of Business Venturing 18(3): 301-331.

http://dx.doi.org/10.1016/S0883-9026(02)00097-6

Dreyfus, H. L.; Dreyfus, S. E. 1986. Mind over machine: the power of human intuition and expertise in the area of the computer. New York: The Free Press.

Edelman, L. F.; Brush, C. G.; Manolova, T. S. 2001. The impact of human and organizational resources on small firm strategy, Journal of Small Business and Enterprise Development 9(3): 236-244. http://dx.doi.org/10.1108/14626000210438562

Edvinsson, L.; Malone, M. 1997. Intellectual capital: realising your company's true value. New York: Harper Collins.

Ellinger, A. E.; Musgrove, C. F.; Ellinger, A. D.; Bachrach, D. G.; Baş, A. B. E.; Wang, Y. L. 2012. Influences of organizational investments in social capital on service employee commitment and performance, Journal of Business Research. (In press).

Frenz, M.; Ietto-Gillies, G. 2009. The impact on innovation performance of different sources of knowledge: evidence from the UK Community Innovation Survey, Research Policy 38: 11251135. http://dx.doi.org/10.1016/j.respol.2009.05.002

Gruman, J. A.; Saks, A. M. 2010. Performance management and employee engagement, Human Resource Management Review 21(2): 123-136. http://dx.doi.org./10.1016/j.hrmr.2010.09.004

Herrmann, A. M.; Peine, A. 2011. When 'National-Innovation-System' meets 'Varieties-of-Capitalism' arguments on labour qualifications: on the skill types and scientific knowledge needed for radical and incremental product innovations, Research Policy 40(5): 687-701. 
Hitt, M. A.; Ireland, R. D.; Lee, H. 2000. Technological learning, knowledge management, firm growth and performance: an introductory essay, Journal of Engineering and Technology Management 17(3-4): 231-246. http://dx.doi.org/10.1016/S0923-4748(00)00024-2

Honig, B. 2001. Human capital and structural upheaval: a study of manufacturing firms in the West Bank, Journal of Business Venturing 16(6): 575-594.

http://dx.doi.org/10.1016/S0883-9026(99)00060-9

Huysman, M. 2000. An organizational learning approach to the learning organization, European Journal of Work and Organizational Psychology 9(2): 133-145.

http://dx.doi.org/10.1080/135943200397905

Johannisson, B. 1999. Networking and entrepreneurial growth, in D. Sexton, H. Landstrom (Eds.). Handbook of Entrepreneurship. London: Blackwell, 368-386.

Joia, L. A. 2000. Measuring intangible corporate assets, Journal of Intellectual Capital 1(1): 68-84. http://dx.doi.org/10.1108/14691930010371636

Kaplan, R. S.; Norton, D. P. 2000. Uravnoteženi sistem kazalnikov. Ljubljana: Gospodarski vestnik.

Kešeljević, A. 2004. Intelektualni kapital kot nadgradnja človeškega in socialnega kapitala, Organizacija 37(1): 43-49.

Kubr, M. 2002. The knowledge consulting a guide to the profession. $4^{\text {th }}$ ed. Geneva: International Labor Office.

Lawler, E. E.; Mohrman, S. A.; Ledford, G. E. 1998. Strategies for high performance organizations - the CEO report. San Francisco: Jossey-Bass Publishers.

Lev, B. 1999. Seeing is believing: a better approach to estimate knowledge capital [online], [cited September 2007]. Available from Internet: http://pages.stern.nyu.edu/ blev/cfoarticle.html

Martocchio, J. J.; Baldwin, T. T. 1997. The evolution of strategic organizational training, Research in Personnel and Human Resources Management 15: 1-46.

Nemec Rudež, H.; Mihalič, T. 2007. Intellectual capital in the hotel industry: a case study from Slovenia, International Journal of Hospitality Management 26(1): 188-199.

http://dx.doi.org/10.1016/j.ijhm.2005.11.002

Nonaka, I. 1994. Dynamic theory of organisational knowledge creation, Organizational Sciences 5(1): 15-37. http://dx.doi.org/10.1287/orsc.5.1.14

Nonaka, I.; Takeuchi, H. 1995. The knowledge creating company: how Japanese companies create the dynamics of innovation. New York: Oxford University Press.

Nonaka, I.; Toyama, R.; Konno, N. 2000. SECI, Ba and leadership: a unified model of dynamic knowledge creation, Long Range Planning 33(1): 5-34.

http://dx.doi.org/10.1016/S0024-6301(99)00115-6

Peters, T. J.; Waterman, R. H. Jr. 1982. In search of exellence. New York: Harper \& Row.

Piazza-Georgi, B. 2002. The role of human and social capital in growth: extending our understanding, Cambridge Journal of Economics 26(4): 461-479. http://dx.doi.org/10.1093/cje/26.4.461

Popper, K. R. 1972. Objective knowledge: an evolutionary approach. Oxford: Clarendon Press.

Praag, M.; Wit, G. 2001. The value of investment in human and social capital for small business founders: frontiers of entrepreneurship research [online], [cited August 2007]. Available from internet: http://www.babson.edu/entrep/fer/Babson2001/VII/VIIB/VIIB.htm ().

Prahalad, C. K; Hamel, G. 1990. The core competence of the corporation, Harvard Business Review 68(3): 79-91.

Pučko, D. 1998. Poslovodenje znanja in vplivi na strateško poslovodenje ter analizo, Organizacija 31(10): 557-565. 
Rodriguez Perez, J.; Ordonez de Pablos, P. 2003. Knowledge management and organizational competitiveness: a framework for human capital analysis, Journal of Knowledge Management 3(7): 82-91. http://dx.doi.org/10.1108/13673270310485640

Roos, J.; Roos, G.; Edvinsson, L; Dragonetti, N. C. 2000. Intelektualni kapital. Ljubljana: Inštitut za intelektualni kapital.

Roper, S.; Arvanitis, S. 2012. From knowledge to added value: a comparative, panel-data analysis of the innovation value chain in Irish and Swiss manufacturing firms, Research Policy 41: 1093-1106. http://dx.doi.org/10.1016/j.respol.2012.03.002

Ruzzier, M; Antončič, B. 2007. Social capital and SME internationalization: an empirical examination, Transformations in Business and Economics 6(1): 122-138.

Sackmann, S.; Flamholz, E.; Bullen, M. 1989, Human resource accounting: a state-of-the-art review, Journal of Accounting Literature 8: 235-264.

Salas, E.; Cannon-Bowers, J. A. 2001. The science of training: a decade of progress, Annual Review of Psychology 52: 471-499. http://dx.doi.org/10.1146/annurev.psych.52.1.471

Santos-Vijande, M. L.; López-Sánchez, J. A.; Trespalacios, J. A. 2012. How organizational learning affects a firm's flexibility, competitive strategy, and performance, Journal of Business Research 65: 1079-1089. http://dx.doi.org/10.1016/j.jbusres.2011.09.002

Schön, D. A. 1973. Beyond the Stable State. Public and private learning in a changing society. Harmondsworth: Penguin.

Stewart, T. A. 2003. Intellectual capital: the new wealth of organization. London: Nicholas Brealey Publishing Limited.

Sveiby, K. E. 1997. The new organizational wealth: managing \& measuring knowledge based assets. San Francisco, CA: Berrett-Koehler Publishers.

Tharenou, P.; Saks, A. M.; Moore, C. 2007. A review and critique of research on training and organizational-level outcomes, Human Resource Management Review 17: 251-273.

http://dx.doi.org/10.1016/j.hrmr.2007.07.004

Tobin, D. R. 1998. The knowledge enabled organization: moving from training to learning to meet business goals. New York: American Management Association.

Tomažič, E. 2003. Z informacijami o neotipljivih virih podjetja do večje kakovosti letnih poročil, Finance, 20 October, 2003.

Wang, H.; Tsui, A. S.; Xin, K. R. 2011. CEO leadership behaviors, organizational performance, and employees attitudes, The Leadership Quarterly 22: 92-105.

http://dx.doi.org/10.1016/j.leaqua.2010.12.009

Watts, A.; Cope, J.; Hulme, M. 1998. Ansoff 's matrix, pain and gain growth strategies and adaptive learning among small food producers, International Journal of Entrepreneurial Behavior and Research 4(2): 101-111. http://dx.doi.org/10.1108/13552559810224567

Werbel, J.; Balkin, D. B. 2010. Are human resource practices linked to employee misconduct? A rational choice perspective, Human Resource Management Review 20: 317-326.

http://dx.doi.org/10.1016/j.hrmr.2009.10.002

Wierzbicki, A. P. 2007. Modelling as a way of organising knowledge, European Journal of Operational Research 176: 610-635. http://dx.doi.org/10.1016/j.ejor.2005.08.018

Zambon, S. 2002. Accounting, intangibles and intellectual capital: an overview of the issuse and some considerations [online], [cited August 2007]. University of Ferrara. Available from Internet: http://www.euintangibles.net/library/localfiles/WP4/4.14_Zambon_2002a.pdf (). 
Doris Omerzel GOMEZELJ, PhD, completed her Master studies at the Faculty of Economics in Ljubljana, Slovenia. She finished her PhD at the UP Faculty of Management Koper. She teaches courses in Entrepreneurship to under- and postgraduate students and actively researches within business and education area. She has authored or co-authored various scientific papers and is currently involved in different national and European projects and networks. Her best papers, presenting the results of her research work, are published in appreciated international scientific journals, as: Industrial Management and Data Systems, Tourism Management, African Journal of Business Management, Baltic Journal of Management, Journal of East European Management Studies.

Boštjan ANTONČI $\check{C}, \mathrm{PhD}$, is Professor of Entrepreneurship. His main research interests include corporate entrepreneurship, entrepreneurial networks, entrepreneurial personality and international entrepreneurship. He has authored or co-authored fourteen books (eleven of them in the area of entrepreneurship) and various scientific research articles. His papers were published in academic journals such as the Journal of Business Venturing, Entrepreneurship and Regional Development, Industrial Management and Data Systems, Journal of Developmental Entrepreneurship, Journal of Enterprising Culture, Managing Global Transitions, Journal of Management Development, and Journal of Small Business and Enterprise Development. 